\title{
Assimilation efficiency in Bufo spinulosus tadpoles (Anura: Bufonidae): effects of temperature, diet quality and geographic origin
}

\author{
Eficiencia de asimilación en larvas de Bufo spinulosus (Anura: Bufonidae): \\ efecto de la temperatura, calidad de dieta y origen geográfico
}

A. GONZALO BENAVIDES ${ }^{1}$, ALBERTO VELOSO ${ }^{1}$, PAULINA JIMÉNEZ ${ }^{1} \&$ MARCO A. MÉNDEZ ${ }^{1,2, *}$

\author{
${ }^{1}$ Departamento de Ciencias Ecológicas, Facultad de Ciencias, Universidad de Chile, Santiago, Chile \\ ${ }^{2}$ Laboratorio de Bioinformática y Expresión Génica, Center for Advanced Studies in Ecology \& Biodiversity \\ \& Laboratorio de Bioestadística, INTA, Universidad de Chile. Santiago, Chile \\ *Corresponding author: mmendez@inta.cl
}

\begin{abstract}
The assimilation efficiency of Bufo spinulosus tadpoles from four localities in Chile was evaluated for two different temperatures $\left(15\right.$ and $25^{\circ} \mathrm{C}$ ) and two different diets (low nutritional quality diet (LQD): $22.28 \mathrm{mg} \mathrm{g}$ $\mathrm{N}^{-1}$; high nutritional quality diet (HQD): $47.53 \mathrm{mg} \mathrm{g} \mathrm{N}^{-1}$ ) using ash as a marker of digestion. Results showed that geographic origin did not affect assimilation efficiency, while the relationship observed between temperature and diet quality was significant. Assimilation efficiency was greater for the HQD when tadpoles were maintained at $15{ }^{\circ} \mathrm{C}$, instead significant differences were not found between diets for tadpoles maintained at $25{ }^{\circ} \mathrm{C}$. Our results suggest that the effect of temperature on digestive processes is more relevant than its effect on transit time in the digestive tract. The differences in size at metamorphosis in $B$ spinulosus populations of distinct geographic origin could not be explained by the existence of differences in physiologic digestive capacities.
\end{abstract}

Key words: Bufo spinulosus, tadpoles, assimilation, temperature effects, diet quality effects, geographic origin effects.

\section{RESUMEN}

La eficiencia de asimilación de materia en larvas de Bufo spinulosus provenientes de cuatro localidades de Chile, fue evaluada para dos temperaturas $\left(15\right.$ y $\left.25{ }^{\circ} \mathrm{C}\right)$ y dos dietas diferentes (pobre: $22,28 \mathrm{mg} \mathrm{g} \mathrm{N}^{-1}$ y rica $47,53 \mathrm{mg} \mathrm{g} \mathrm{N}^{-1}$ ), utilizando la ceniza como marcador de digestión. Los resultados mostraron que la localidad de origen de las larvas no afecta la eficiencia de asimilación, mientras que se registró una interacción significativa entre la temperatura y la calidad de la dieta. La eficiencia de asimilación es mayor para la dieta rica cuando las larvas fueron mantenidas a $15{ }^{\circ} \mathrm{C}$, no existiendo diferencias entre dietas cuando fueron mantenidas a $25{ }^{\circ} \mathrm{C}$. Nuestros resultados sugieren que para B. spinulosus el efecto de la temperatura sobre los procesos digestivos es más relevante que su efecto sobre el tiempo de tránsito en el tracto digestivo. Las diferencias en el tamaño alcanzado a la metamorfosis en poblaciones de B. spinulosus de origen geográfico distinto, no podrían ser explicadas por la existencia de diferencias en las capacidades fisiológicas digestivas.

Palabras clave: Bufo spinulosus, larvas, asimilación, efecto temperatura, efecto calidad de dieta, efecto localidad geográfica.

\section{INTRODUCTION}

As other ectotherms, amphibians do not posses an efficient mechanism for physiological thermoregulation (Duellmann \& Trueb 1984, Schmid-Nielsen 1997), thus determining their strong dependence of growth and differentiation process upon temperature (Atkinson 1994, 1996,
Alvarez \& Nicieza 2002a). Temperature and the availability of nutrients have been considered the most important causes in the variation in size and age at metamorphosis (Beck 1997, Alvarez \& Nicieza 2002a). Several studies have shown that, among individuals having recently metamorphosed, variation in food availability and diet quality during larval stage can affect the 
rate of differentiation, the size at metamorphosis and the capacity to escape predators (Travis \& Trexler 1986, Beck 1997, Denver 1997, Kupferberg 1997, Newman 1998, Reading \& Clarke 1999, Beck \& Congdon 2000, Nicieza 2000, Alvarez \& Nicieza 2002b, Loman 2002). Due to diets of highest nutritional quality generally produce an increase in the rates of growth and differentiation, it is assumed that the amount of energy and nutrients present in high quality foods would be better utilized by tadpoles. However, the energy that an organism obtain from food is mainly dependent upon its digestion (i.e., hydrolysis) and assimilation (i.e., absorption) capacity (Sibly 1981, Calow 1985, Sibly \& Calow 1986). Assimilation efficiency reflects the capacity of an organism to metabolize the nutrients present in ingested food and is an important factor in its energy balance (Calow 1985). Changes in assimilation efficiency have been described in ectotherms, allowing them to utilize different types of foods more efficiently (Horn 1989, Benavides el al. 1994). In tadpoles, Alvarez \& Nicieza (2002a) show that dietary selection determines maximum size at metamorphosis and a short larval period. However, available information concerning the importance of digestive performance in explaining differences in amphibian life-history attributes is scarce and fragmented (Larsen 1992, Alford 1999, Skelly \& Golon 2003).

Bufo spinulosus Wiegmann 1835 has an extended geographic distribution from the Peruvian-Bolivian highlands to the Chilean and Argentinean Andes (Vellard 1959). In Chile, this species has a latitudinal distribution from Arica $\left(18^{\circ} 30^{\prime} \mathrm{S}, 70^{\circ} 13^{\prime} \mathrm{W}, 164 \mathrm{~m}\right)$ to the Andes mountains near Santiago (33⒉ 'S, $70^{\circ} 18^{\prime}$ W; $2,333 \mathrm{~m}$ ), and an altitudinal distribution from sea level (only in Arica) to 4,600 m of altitude (Cei 1962, Veloso et al. 1982, Veloso \& Navarro 1988). This particular distribution allows us to find larvae and adults of this species living in different environments, with water temperatures ranging between $25-30{ }^{\circ} \mathrm{C}$ in the locality of Tatio $\left(4,450 \mathrm{~m}\right.$; northern Chile) to $15-22{ }^{\circ} \mathrm{C}$ in Farellones (2,233 m, in central Chile). Recently, Méndez et al. (2004) find high levels of both morphological and genetic differentiation among populations of $B$. spinulosus. These authors propose also that local abiotic conditions, especially water temperature, could explain the adults morphological divergence observed in individuals from the Tatio population, which represents an extreme in the morphological variation observed for this species. Concerning larval stages Benavides (2003) described that Bufo spinulosus tadpoles from different geographic localities, exposed in laboratory to identical photoperiod, temperature and diet conditions, reach to different sizes at metamorphosis. These results suggest that among populations of this species could be differences in some physiological attributes, and these differences possibly will determine the development and growth of the tadpoles and adults size in this species. Given the wide geographical distribution of $B$. spinulosus, this species is an adequate experimental model for exploring physiological variation among tadpoles of different populations.

Because it has been described the importance of the temperature in the development and digestive processes of tadpoles (Hochachka \& Somero 1984, Rome et al 1992, Alford 1999, Alvarez \& Nicieza 2002a), and given that water temperature to which larvae inhabit could be different along the range of geographic distribution, temperature could influence the levels of phenotypic variation observed in natural habitats (Ståhlberg et al. 2001). Therefore, the inclusion of temperature in studies of dietary assimilation capacity is an important point, which up to date has been scarcely explored. We hypnotized that in $B$. spinulosus tadpoles exists differences in the capacities to assimilate the ingested foods as a function of geographic origin and the thermal environmental where tadpoles inhabit. We predict that tadpole feed with rich nutritional diet and growing at high temperature will show higher assimilation in comparison to tadpoles growing both a lower temperature and a nutritional quality diet. We also predict that will exist differences in assimilation among larval as a function of geographic precedence.

\section{MATERIAL AND METHODS}

Bufo spinulosus larvae were collected from four localities from the northern and central zones of Chile: Chusmiza, a mountain stream located at $3,213 \mathrm{~m}$ of altitude in Region I $\left(19^{\circ} 40^{\prime} \mathrm{S}, 69^{\circ} 10^{\prime} \mathrm{W}\right)$; El Tatio, a stream of natural hot spring water located at 4,264 $\mathrm{m}$ of 
altitude in Region II $\left(22^{\circ} 20^{\prime} \mathrm{S}, 68^{\circ} 01^{\prime} \mathrm{W}\right)$; Quebrada Chita, a pond that is permanently supported by superficial drainage and located at $3,741 \mathrm{~m}$ of altitude in Region II $\left(22^{\circ} 25^{\prime} \mathrm{S}\right.$, $68^{\circ} 10^{\prime} \mathrm{W}$ ); and Farellones, a mountain stream located at $2,331 \mathrm{~m}$ of altitude in the central zone $\left(33^{\circ} 21^{\prime} \mathrm{S}, 70^{\circ} 18^{\prime} \mathrm{W}\right)$. During the capturing period (spring-summer 2001 and 2002) water temperatures during the day and night were similar for Chusmisa, Quebrada Chita, and Farellones $\left(25\right.$ and $6{ }^{\circ} \mathrm{C}$, respectively), however in El Tatio the observed temperature $\left(23^{\circ} \mathrm{C}\right)$ was similar during the day and at night (Benavides 2003).

The larvae from El Tatio and Chita were directly collected during spring 2002, while the larvae from Chusmiza and Farellones were obtained via artificial reproduction of individuals collected during spring 2001. Once the larvae reached a Gosner (1960) stage between 21 and 23 (1960) they were randomly placed at a density of 15 individuals $600 \mathrm{~mL}^{-1}$, in plastic containers of a $1 \mathrm{~L}$ capacity and a photoperiod of 12L:12D. For each geographic locality 12 containers were used; six were maintained at a temperature of $15 \pm 1{ }^{\circ} \mathrm{C}$ and six at $25 \pm 1{ }^{\circ} \mathrm{C}$. For each temperature treatment and locality of origin, three replicates were used for each of two diet treatments: a low nutritional quality diet (LQD) consisting in boiled lettuce and a high nutritional quality diet (HQD) consisting in the microalgae spirulina (Wardley Spirulina Plus). All containers were checked every $24 \mathrm{~h}$ to guarantee the availability of food. Water in the containers was changed every $72 \mathrm{~h}$ and then the containers were randomly rearranged. After two weeks each group of tadpoles were transferred to a container with clean water without food. During the following $2 \mathrm{~h}$, the feces produced by each group of tadpoles were collected with a Pasteur pipette. All the feces were immediately centrifuged at $2,500 \mathrm{rpm}$ for $10 \mathrm{~min}$ and transferred to aluminum foil containers, which were previously burned at $550{ }^{\circ} \mathrm{C}$ for $4 \mathrm{~h}$ and weighted with a precision of $0.0001 \mathrm{~g}$. The collected feces were dried to a constant mass (approximately $48 \mathrm{~h}$ ) in a drying oven at $55^{\circ} \mathrm{C}$. Each container was then weighted in order to determine the quantity of dry material present, burned for six hours at $550{ }^{\circ} \mathrm{C}$, and weighted to determine the ash remainder. Since it was impossible to measure the quantity of food consumed by the larvae, assimilation efficiency (AE), also called apparent digestibility (Sibly 1981), was determined through the following method (Montgomery \& Gerking 1980):

$\mathrm{AE}=[1-(\%$ ash in $\operatorname{diet} / \%$ ash in feces $)] * 100$.

Estimation of AE by using ash as a marker of digestion could produce an underestimation (but not an overestimation) of real assimilation if a fraction of ash is absorbed by individual or lost in the feces during contact with the water (Montgomery \& Gerking 1980, Sibly 1981, Bjorndal 1985). However, assuming that the absorption of ash is constant for all of the diets and the time remains in water was the same; this type of error is acceptable to determine the comparative assimilation efficiency. The assimilation values for each treatment were calculated as an average of the percent assimilation obtained for each three samples and expressed as percent assimilation efficiency with a standard error. For the statistical analysis of the results, three-way ANOVAs were used with locality, temperature and diet as the predicting factors. In order to satisfy the normality requirements of the data, the assimilation efficiency were transformed using: Arcsine [SQR (AE / 100)]. Homogeneity of the variances were evaluated using the Cochran test $(\mathrm{P}>0.2$ for each case). The Tukey test (HSD) was used to establish differences among samples. All analyses were carried out using the program STATISTICA 6.0 (Statsoft 2004).

Before the experiments, the ash content of the two experimental diets was determined using the same procedure describe above, and the energy content (kJ per dry ash weight) was determined by combustion in a PARR 1261 bomb. Total nitrogen $\left(\mu \mathrm{g} \mathrm{mg}^{-1}\right)$ was determined by the Kjeldahl method modified by Muhlhauser \& Soto (1987). The HQD presented lower ash content (6.9 and $11.22 \%$, respectively), higher energy content per ash-free weight $(14.21 \mathrm{~kJ}$ and $10.23 \mathrm{~kJ}$, respectively) and a greater total nitrogen content (47.53 and $22.28 \mu \mathrm{g} \mathrm{mg}^{-1}$ ) as compared to the LQD.

\section{RESULTS}

Because it is possible that the assimilation values obtained in our experiment could be 
influenced by comparing individuals produced by artificial reproduction (Chusmiza and Farellones) with individuals collected directly from localities (Tatio Chita), we performed a test in which we compared assimilation values categorizing by two conditions: laboratory or collected larvae. This test showed that there was no differences between these categories (Student t-test, $\mathrm{t}=-0.260, \mathrm{df}=46, \mathrm{P}=0.610$ ). According that, the above conditions it seems no affect the response evaluated in our experiment.

At $15{ }^{\circ} \mathrm{C}$ the observed $\mathrm{AE}$ varied from 75.7 $\%$ for LQD and $91 \%$ for HQD. Contrary to our predictions, the individuals from different geographic localities presented similar AE values for both experimental diets. (Table 1, Fig. 1). However, the AE of food was shown to be significantly affected by the environmental temperature, type of diet and by the interaction between temperature and diet (Table 1, Fig. 1). In this analysis we detected a marginal interaction among locality, diet and temperature that could suggest that assimilation of both diet and temperature regimes could changes depending of locality considered. In order to explore this possibility this effect, we performed a comparison of estimated marginal means of this interaction by locality, considering temperature and diet. According to this analysis in all cases considered assimilation values have similar mean value independent of locality (considering $95 \%$ confidence interval, data not shown). Take account the above information, we discard locality as a relevant factor in order to explain assimilation differences observed among tadpoles.

The Tukey test showed that at $15^{\circ} \mathrm{C}$ the $\mathrm{AE}$ of food in LQD is lower than LQD that AE at $25^{\circ} \mathrm{C}$, and that HQD at both temperatures (Tukey test, $\mathrm{P}<0.05$ ). In addition, the HQD presented greater AE values than the LQD (Fig 1). While AE for the $\mathrm{LQD}$ increased at $25^{\circ} \mathrm{C}$, the HQD did not present and significant differences between the two temperatures.

\section{DISCUSSION}

The AE values obtained for B. spinulosus tadpoles are in the range previously described for amphibian tadpoles, varying from $2 \%$ in $R$. dalmatiana (Waringer-Loschenkohl \& Schagerl 2001) and $7.8 \%$ in R. catesbiana (Altig \& McDearman 1975), to higher values of $80 \%$ in $R$. dalmatiana (Waringer-Loschenkohl \& Schagerl 2001) and $85.7 \%$ in G. carolinensis (Altig \& McDearman 1975). These latter values are comparable to our results for $B$. spinulosus tadpoles, where the highest assimilation values were found for the HQD. The spirulina-based diet (HQD) could be considered to be the more artificial of the two used, in its high AE values are comparable to observed values in other species when artificial diets are used (i.e., rabbit pellets: Altig \& McDearman 1975; Spyrogira: Waringer-Loschenkohl \& Schagerl 2001).

TABLE 1

ANOVA results for assimilation efficiency of Bufo spinulosus tadpoles for different geographic origins, maintained at two temperatures $\left(15\right.$ and $\left.25^{\circ} \mathrm{C}\right)$ and fed diets of low and high nutritional quality (see text)

Resultado del ANOVA para eficiencia de asimilación de larvas de Bufo spinulosus de diferentes localidades de origen, mantenidas a dos temperaturas $\left(15\right.$ y $\left.25^{\circ} \mathrm{C}\right)$ y alimentadas con una dieta pobre y rica (ver texto)

\begin{tabular}{|c|c|c|c|c|c|}
\hline Factor & Sum of squares & Degrees of freedom & Mean square & F-value & P-value \\
\hline Locality & 0.00101 & 3 & 0.00034 & 0.33 & 0.807110 \\
\hline Diet & 0.18980 & 1 & 0.18980 & 183.54 & 0.000000 \\
\hline Temperature & 0.01037 & 1 & 0.01037 & 10.02 & 0.003383 \\
\hline Diet x locality & 0.00091 & 3 & 0.00030 & 0.29 & 0.828956 \\
\hline Temperature $\mathrm{x}$ locality & 0.00254 & 3 & 0.00085 & 0.82 & 0.493071 \\
\hline Diet $\mathrm{x}$ temperature & 0.02514 & 1 & 0.02514 & 24.31 & 0.000024 \\
\hline Locality $\mathrm{x}$ diet $\mathrm{x}$ temperature & 0.00883 & 3 & 0.00294 & 2.85 & 0.052973 \\
\hline Error & 0.03309 & 32 & 0.00103 & & \\
\hline
\end{tabular}




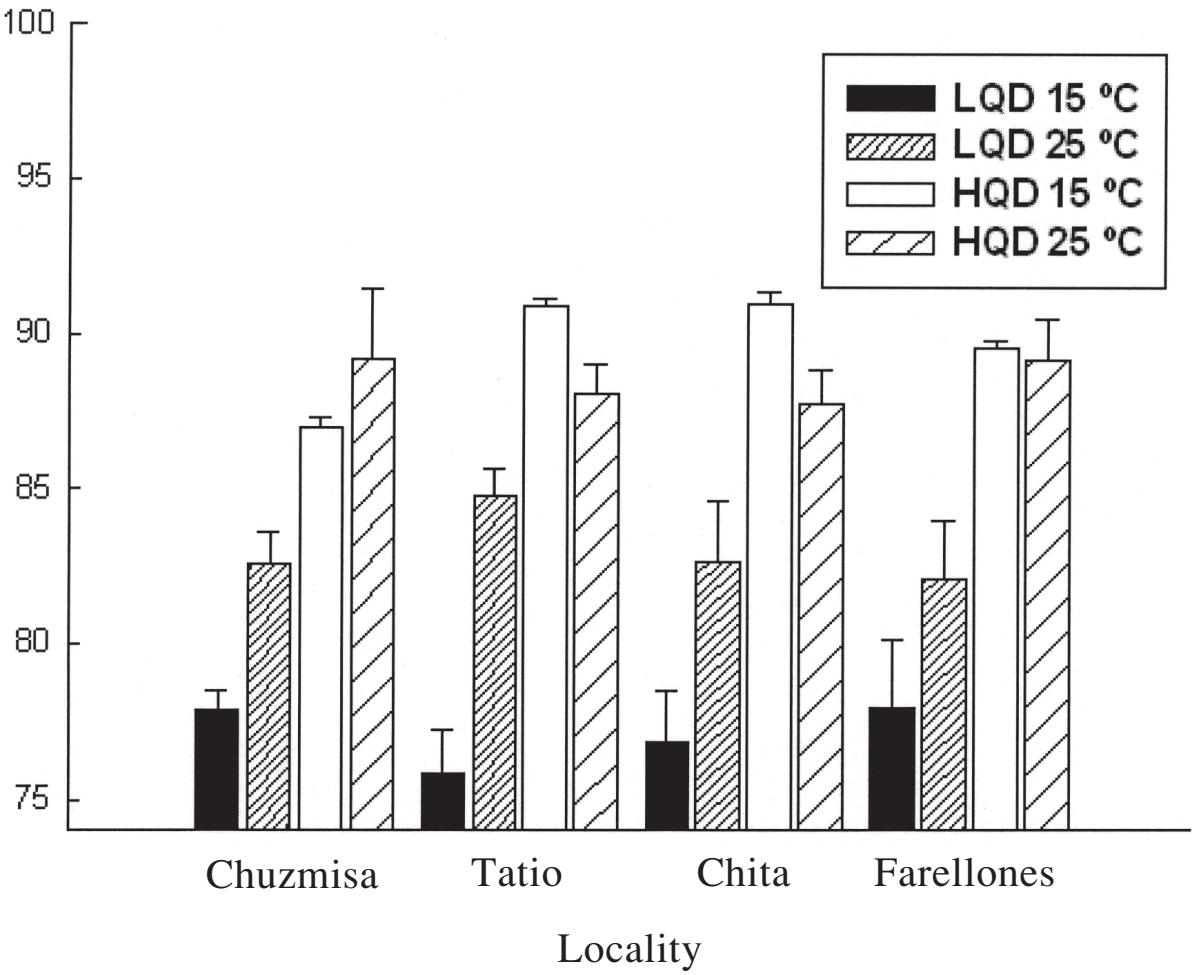

Fig. 1: Assimilation efficiency of Bufo spinulosus tadpoles of different geographic origin, maintained at two temperatures: 15 and $25{ }^{\circ} \mathrm{C}$, fed with boiled lettuce (LQD) and spirulin-based food (HQD). Error bars correspond to SE.

Eficiencia de asimilación en larvas de Bufo spinulosus provenientes de distintas localidades y mantenidas a dos temperaturas: 15 y $25^{\circ} \mathrm{C}$, alimentadas con una dieta de lechuga hervida (DP) y alimento en base a espirulina. Las barras de error corresponden al EE.

Environmental temperature has traditionally been considered as one of the most relevant factors affecting the physiology of poikilotherms (Rome et al. 1992, Duellman \& Trueb 1994, Schmidt-Nielsen 1997) and its effect on digestive physiology has received considerable attention (e.g., Coulson 1990, Nicieza et al. 1994, McConnachie \& Alexander 2004). It has been described that an increase in temperature increases assimilation of food (Altig \& McDearman 1975, Nicieza et al. 1994, McKinon \& Alexander 1999, McConnachie \& Alexander 2004). This pattern coincides with our results in $B$. spinulosus tadpole fed with a LQD. This higher assimilation observed could be explained by the increase in the hydrolysis and absorption of nutrients from food (Penry 1993), which are temperature-dependent processes (Hochachka \& Somero 1984, Rome el al.1992). This increase in assimilation performance due to the increase of temperature would cancel the negative effect that the decrease in transit time has on assimilation (Elliot 1972). However, the digestibility of the HQD is not affected by temperature. We do not have an explanation for this phenomenon, however we can propose that the HQD is an artificial diet consisting of partially hydrolyzed elements, which are more easily digested and absorbed by the larvae as Altig \& McDearman (1975) and Alford (1999) suggested. Therefore, it is feasible that at $15^{\circ} \mathrm{C}$, the HQD could be digested and assimilated near to the maximum capacity $(100 \%)$, for which an increase in temperature would not cause a detectable increase in its AE.

The efforts directed toward understanding and explaining the physiological diversity in animals has been concentrated in comparative studies between species from different habitats. However, very few studies have focused on the intraspecific variability at either the intra-or 
inter-individual levels. Moreover, studies oriented toward understanding thermal acclimation at the population level are scarce (Marquet el al. 1998). The possible geographic variation in the expression of attributes in amphibians, such as growth and its association with temperature, has only recently been included by some authors (i.e., Ståhberg et al. 2001, Laugen et al. 2003). Considering the geographic variation in the digestive physiology of other ectotherms (i.e., Salmo salar, Nicieza et. al. 1994), our proposition point to the fact that $B$. spinulosus would exhibit a similar pattern. However, our results do not support this hypothesis. One possible explanation is that the levels of $\mathrm{AE}$ could be influenced by the similarity between natural diets and/or due to the probable existence of phenotypic flexibility in the digestive biochemistry of the larvae. This phenomenon would allow for constant levels of nutrient extraction in spite of the differences in the type and quality of the nutrients (Toloza 1990a, 1990b, Sabat \& Bozinovic 1996). Although there is a lack of systematic studies on the larvae diet of this species, preliminary data from two localities (Tatio and Farellones) indicates that the larvae consume algae that are similar in total energy and total nitrogen content (Benavides, unpublished data). Therefore, if the larvae from different studied localities consume equivalent diets, it would be reasonable to assume that their digestive biochemical processes are similar (Toloza 1990a).

The results of the present study are affected by the use of diets not regularly consumed by the tadpoles. However, both experimental diets utilized are similar in composition (i.e., of vegetable origin) and allow the $B$. spinulosus larvae to successfully reach metamorphosis with a very low mortality rate (Benavides 2003), suggesting that they are nutritionally adequate. Although the use of artificial diets is a common problem in many experimental designs (Altig \& McDearman 1975, Álvarez \& Nicieza 2002a, $2000 \mathrm{~b}$ ), their usefulness in comparative studies concerning digestive function of these organisms has been previously demonstrated (i.e., Sabat \& Bozinovic 2000). Taking into consideration this, our results suggest that the physiological adjustments in the rates of development of the different populations cannot be attributed to assimilation. Therefore, the explanations for the detected differences in size at metamorphosis of
B. spinulosus larvae from different geographic localities could be a consequence of the differential effect of temperature on the metabolism and growth of larvae from different geographic localities. We are currently performing research in order to elucidate the effects of geographic variation on life-history traits in this species.

\section{ACKNOWLEDGEMENTS}

The authors wish to thank Eduardo Soto, Soledad Cortez, Claudio Correa, Marcela Márques, Juan Opazo, Marco Lardies and Mauricio Soto for their collaboration in the field and in the laboratory experiment. The authors would also like to thank Dr. Pablo Sabat and three anonymous referees for their constructive suggestions to the former version of this manuscript. Finally, we would like to give special thanks to Dr. Mario Rosenmann for his permanent friendship and help. Financial support was provided by the projects FONDECYT 3000048 to MAM, MILENIO P99-103F ICM to PJ and Departamento de Posgrado y Postítulo of Universidad de Chile, Fellowships PG 55/99 and PG 23/200 to GB.

\section{LITERATURE CITED}

ALFORD RA (1999) Ecology, resource use, competition and predation. In: McDiarmid W \& R Altig (eds) Tadpole: the biology of anuran larvae: 240-278. The University of Chicago Press, Chicago, Illinois, USA.

ALTig R \& W McDEARMAN (1975) Percent assimilation and clearance times of five anuran tadpoles. Herpetologica 31: 67-69.

ÁLVAREZ D \& G NICIEZA (2002a) Effects of temperature and food quality on anuran larval growth and metamorphosis. Functional Ecology 16: 640-648.

ÁLVAREZ D \& G NICIEZA (2002b) Effects of induced variation in anuran larval development on postmetamorphic energy reserves and locomotion. Oecologia 131: 186-195.

ATKINSON D (1994) Temperature and organism size - A biological law for ectotherms? Advances in Ecological Research 25: 1-58.

ATKINSON D (1996) Ectotherm life-history responses to developmental temperature. In: Johnston IA \& Bennett AF (eds) Animals and temperature, phenotypic and evolutionary adaptation: 183-204. Society for Experimental Biology Seminar Series 59.

BECK CW (1997) Effect of changes in resource level on age and size at metamorphosis in Hyla squirella. Oecologia 112: 187-192. 
BECK CW \& JD CONGDON (2000) Effects of age and size at metamorphosis on performance an metabolic rates of southern toad, Bufo terrestris metamorphs. Functional Ecology 14: 32-38.

BENAVIDES AG (2003) Biología térmica de Bufo spinulosus (Anura: Bufonidae): una comparación interespecífica. Tesis de Doctorado, Facultad de Ciencias, Universidad de Chile, Santiago, Chile. vii $+93 \mathrm{pp}$

BENAVIDES AG, JM CANCINO \& FP OJEDA (1994) Ontogenetic change in the diet of Aplodactylus punctatus (Pisces: Aplodactylidae): an ecophysiological explanation. Marine Biology 118: 1-5.

BJORNDAL KA (1985) Use of ash an indigestible dietary marker. Bulletin of Marine Society 36: 224-230.

CALOW P (1985) Adaptive aspects of energy allocation. In: Tyler P \& P Calow (eds) Fish energetics: new perspectives: 13-32. Croom Helm Ltd., Kent, United Kingdom.

CEI J (1962) Batracios de Chile. Ediciones Universidad de Chile, Santiago, Chile. cviii +128 pp.

COULSON RA, TD COULSON \& JD HERBERT (1990) How do digestion and assimilation rates in alligators vary with temperature? Comparative Biochemistry and Physiology 96A: 441-449.

DENVER RJ (1997) Proximate mechanisms of phenotypic plasticity in amphibian metamorphosis. American Zoologist 37: 172-184.

DUELLMANN WE \& L TRUEB (1994) Biology of Amphibians. McGraw-Hill, New York, New York, USA. xxi $+670 \mathrm{pp}$.

ELLIOT JM (1972) Rates of gastric evacuation in brown trout, Salmo truta L. Freshwater Biology 2: 1-18.

GOSNER KL (1960) A simplified table for staging anuran embryos with notes on identification. Herpetologica 16: 183-190.

HOCHACHKA PW \& GN SOMERO (1984) Biochemical adaptation. Princeton University Press, New York, New York, USA. 537 pp.

HORN MH (1989) Biology of marine herbivorous fishes. Oceanography and Marine Biology: An Annual Review 27: 167-272

KUPFERBERG SJ (1997) The role of larval diet in anuran metamorphosis. American Zoologist 37: 146-159.

LARSEN LO (1992) Feeding and digestion. In: Feeder ME \& WW Burggren (eds) Environmental physiology of the amphibians: 378-395. University if Chicago Press, Chicago, Illinois, USA

LAUGEN AT, A LAURILA \& J MERILÄ (2003) Latitudinal and temperature-dependent variation in embryonic development and growth in Rana temporaria. Oecologia 135: 548-554.

LOMAN J (2002) Temperature, genetic and hydroperiod effects on metamorphosis of brown frogs Rana arvalies and $R$. temporaria. Journal of Zoology (London) 258: 115-129.

MARQUET P, F BOZINOVIC, GA BRADSHAW, C CORNELIUS, H GONZÁLES, J GUTIÉRREZ, E HAJEK, JA LAGOS, F LÓPEZ-CORTEZ, L NÚÑEZ, EF ROSELLO, C SANTORO, H SAMANIEGO, VG STANDEN, JC TORRESMURA \& F JAKSIC (1998) Los ecosistemas el desierto de Atacama y área andina adyacente en el norte de Chile. Revista Chilena de Historia Natural 77: 593-617.

McCONNACHIE S \& GJ ALEXANDER (2004) The effect of temperature on digestive and assimilation efficiency, gut passage time and appetite in an ambush foraging lizard, Cordylus melanotus melanotus. Journal of Comparative and Biochemical Physiology 174B: 99-105.
McKINON W \& GJ ALEXANDER (1999) Is temperature independence of digestive efficiency and experimental artifact in lizards? a test using the common flat lizard (Platysaurus intermedius). Copeia 1999: 299-303.

MÉNDEZ MA, ER SOTO, C CORREA, A VELOSO, M SALLABERRY \& P ITURRA (2004) Morphological and genetic differentiation among Chilean populations of Bufo spinulosus (Anura: Bufonidae). Revista Chilena de Historia Natural 77: 559-567.

MONTGOMERY L \& SD GERKING (1980) Marine macroalgae as foods for fishes: an evaluation of potential food quality. Environmental Biology of Fishes 5: 143-153.

MUHLHAUSER HA \& L SOTO (1987) Improvement of the Kjeldahl Method for total nitrogen including Acid-Hydrolysable Phosphorus determinations in freshwater ecosystems. International Journal of Environmental and Analytical Chemistry 28: 215226.

NEWMAN RA (1998) Ecological constrains on amphibian metamorphosis: interactions of temperature and larval density with responses to changing food level. Oecologia 115: 9-16.

NICIEZA AG (2000) Interacting effects on predation risk and food availability on larval anuran behavior and development. Oecologia 123: 497-505.

NICIEZA AG, L REIRIZ \& F BRAÑA (1994) Variation in digestive performance between geographically disjunct populations of Atlantic salmon: countergradient in passage time and digestion rate. Oecologia 99: 243-251.

PENRY P (1993) Digestive constraints on diet selection. In: Hughes RN (ed) Diet selection: an interdisciplinary approach to foraging behaviors: 32-55. Blackwell Scientific Publications, Oxford, United Kingdom.

READING CJ \& RT CLARKE (1999) Impacts of climate and density on the duration of the tadpole stage of the common toad Bufo bufo. Oecologia 121: 310-315.

ROME LC, ED STEVENS \& HB JOHN-ALDER (1992) The influence of temperature and thermal acclimation on physiological function. In: Feeder ME \& WW Burggren (eds) Environmental physiology of the amphibians: 183-249. University of Chicago Press, Chicago, Illinois, USA.

SABAT P \& F BOZINOVIC (1996) Dietary chemistry and allometry of intestinal disaccharidases in the toad Bufo spinulosus. Revista Chilena de Historia Natural 69: 387-391.

SABAT P \& F BOZINOVIC (2000) Digestive plasticity and the cost of acclimation to dietary chemistry in the omnivorous leaf-eared mice Phyllotis darwini. Journal of Comparative Physiology 170B: 411-417.

SCHMIDT-NIELSEN K (1997) Animal physiology: adaptation and environment. Fifth edition. Cambridge University Press, New York, New York, USA. ix +607 pp.

SIBLY RM (1981) Strategies of digestion and defecation. In: Twonsend CR \& P Calow (eds) Physiological ecology: an evolutionary approach to resource use: 109-139. Blackwell Scientific Publications, Oxford, United Kingdom.

SIBLY RM \& P CALOW (1986) Physiological ecology of animals: an evolutionary approach. Blackwell Scientific Publications, London, United Kingdom. ix +179 pp.

SKELLY DK \& J GOLON (2003) Assimilation of natural benthic substrates by two species of tadpoles. Herpetologica 59: 37-42. 
STÅHLBERG F，M OLSSON \& T ULLER (2001) Population divergence of developmental thermal optima in Swedish common frogs, Rana temporaria. Journal of Evolutionary Biology 14: 755-762.

STATSOFT, INC (2004) STATISTICA (data analysis software system), version 6. www.statsoft.com.

TOLOZA EM \& JM DIAMOND (1990a) Ontogenetic development of nutrient transporters in bullfrog intestine. American Journal of Physiology 258: G760-G769.

TOLOZA EM \& JM DIAMOND (1990b) Ontogenetic development of transporter regulation in bullfrog intestine. American Journal of Physiology 258: G770-G773.

TRAVIS J \& JC TREXLER (1986) Interactions among factors affecting growth, development and survival in experimental populations of Bufo terrestris (Anura: Bufonidae). Oecologia 699: 110-116.

Associate Editor: Francisco Bozinovic

Received December 2, 2004; accepted March 1, 2005
VELOSO A \& J NAVARRO (1988) Lista sistemática y distribución geográfica de anfibios y reptiles de Chile. Bolletino del Museo Regionale di Scienze Naturali, Torino 6: 481-539.

VELOSO A, M SALLABERRY, J NAVARRO, P ITURRA, J VALENCIA, M PENNA \& N DÍAZ (1982) Contribución sistemática al conocimiento de la herpetofauna del extremo norte de Chile. El hombre y los ecosistemas de montaña: 135-265. MAB 6. Santiago, Chile.

WARINGER-LOSCHENKOHI A \& M SCHAGERL (2001) Algal exploitation by tadpoles: an experimental approach. International Review of Hydrobiology 86: 105-125.

VELLARD J (1959) El género Bufo, estudios sobre batracios andinos. Noticiero Mensual del Museo Nacional Historia Natural (Chile) 8: 1-48. 